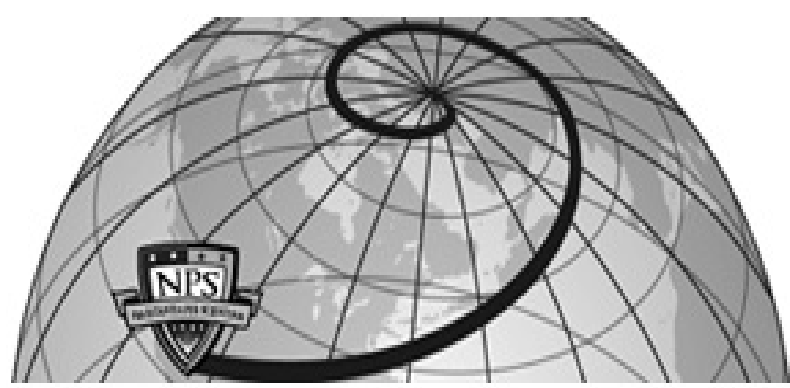

Calhoun: The NPS Institutional Archive DSpace Repository

Cost-efficiencies, profitability, and strategic behavior: evidence from Japanese commercial banks

Hensel, Nayantara D.

Emerald Group Publishing Limited

International Journal of Managerial Finance, v.2, no.1, 2006, pp. 49-76.

https://hdl.handle.net/10945/38014

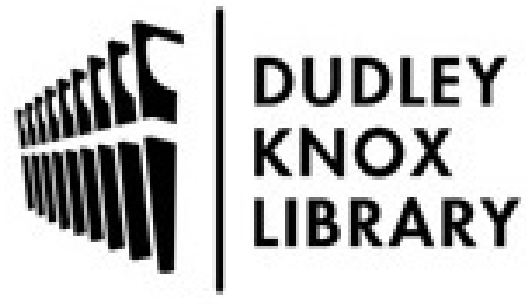

http://www.nps.edu/library
Calhoun is the Naval Postgraduate School's public access digital repository for research materials and institutional publications created by the NPS community. Calhoun is named for Professor of Mathematics Guy K. Calhoun, NPS's first appointed -- and published -- scholarly author.

Dudley Knox Library / Naval Postgraduate School 411 Dyer Road / 1 University Circle Monterey, California USA 93943 


\section{Cost-efficiencies, profitability, and strategic behavior: evidence from Japanese commercial banks}

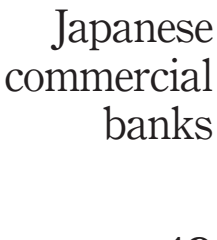

\begin{abstract}
Purpose - To examine whether Japanese commercial banks exhibited economies of scale and economies of density at the time when the mega-merger wave in Japanese banking began in the late 1990s. Since this merger wave has not yielded efficiencies, this analysis aims to shed light on whether banks, at the start of the wave, had reason to believe that larger banks would be more efficient.

Design/methodology/approach - Using a modified version of the translog cost function, the analysis estimates economies of scale and economies of density for Japanese city banks, trust banks, and regional banks. Then, the relationship between size and economies of scale/density and that between profitability and scale/density are explored using regression analysis.

Findings - Results suggest that larger banks (as measured by value of assets/loans/ deposits/investments, and number of employees/branches) were more likely to be in the decreasing/constant returns to scale/density region than smaller banks, The finding was statistically significant for all three types of Japanese banks. On average, city banks exhibited diseconomies of scale/density; trust banks exhibited constant returns to scale and increasing returns to density, and regional banks exhibited increasing returns to scale and density. This suggests that unions between city banks and either regional banks or trust banks may have been more likely to yield cost-efficiencies, and raises questions concerning the efficiency motivations of the mega-bank mergers. The findings further indicate that banks with higher sales were more likely to have exploited scale/density efficiencies, and that banks with higher net incomes were more likely to be in the increasing returns region.

Originality/value - This paper suggests that the mega-merger wave in Japan in the late 1990s may not have been motivated by a desire for greater efficiencies through utilization of under-utilized branch networks. Unlike other studies, this analysis differentiates between economies of scale and economies of density.
\end{abstract}

Keywords Banking, Japan, Consolidation, Regression analysis

Paper type Research paper

\section{Introduction}

The Japanese economy has been confronted with the need for substantive reform in a variety of areas. Since the late 1990s, mergers and acquisitions have been frequent as the Japanese economy tries to make a recovery. Various legal provisions have made

The author would like to thank Pankaj Ghemawat, Dale Jorgenson, W. Carl Kester, Richard Caves, Kathryn Dewenter, and two anonymous referees at the International Journal of Managerial Finance for suggestions and comments. Thanks are gratefully acknowledged for the research support from the US Naval Postgraduate School, Harvard Business School and the National Bureau of Economic Research. All errors are entirely the authors. Please do not quote or cite without permission of author.

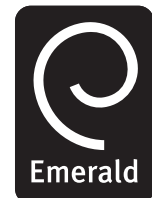

International Journal of Managerial Finance

Vol. 2 No. 1, 2006 pp. $49-76$

(c) Emerald Group Publishing Limited 1743-9132 
IJMF

2,1
M\&A activity easier - revisions to the Commercial Code in 1997 simplified merger reporting requirements and procedures, revisions to the antimonopoly laws in 1998 reduced the number of companies subject to the reporting requirements, and further revisions to the Commercial Code in May, 2000 introduced mechanisms for corporate spin-offs (Rafferty, 2000). Beginning in 1999, M\&A activity increased substantially to $\$ 152$ billion in transaction value, relative to $\$ 7.9$ billion in 1998 (Rafferty, 2000).

The M\&A wave was particularly substantial in the banking sector, which concentrated the assets of the banking industry into 5-6 major banking groups through the mergers of "city banks": the merger between Sumitomo Bank and Sakura Bank was announced in October, 1999; the merger between Tokai Bank, Asahi Bank, and Sanwa Bank was announced in March, 2000 (formed UFJ, which was the fourth largest bank in Japan by 2004), the merger between the Bank of Tokyo-Mitsubishi and Mitsubishi Trust was announced in April, 2000 (formed the Mitsubishi Tokyo Financial Group, which was the second largest bank in Japan by 2004), the merger between Dai-Ichi Kangyo Bank, Fuji Bank, and IBJ was announced in August, 1999 (formed the Mizuho Financial Group, which is the largest bank in Japan), and the merger between Mitsui Trust and Banking and Chuo Trust and Banking was announced in January, 1999.

The stated rationale behind these large bank mergers announced during 1999-2000 at the time was that "bigger is better". It is unclear if the banks considered "bigger is better" to mean that larger banks created from the merger would be more likely to be efficient in achieving economies of scale and economies of density. The press surrounding the mergers suggested a different conception of "bigger is better" in that the creation of bigger banks through mergers would enable the larger banks to: strengthen their balance sheets since banks which merged would be eligible for more government funds (Wall Street Journal, 1999); and be less small and vulnerable in facing competitors in the wake of the banking consolidation wave in the US and Europe (Wall Street Journal, 1999).

These benefits from "bigger is better" did not necessarily imply that the bigger banks created from the merger would be more likely to have exploited economies of scale or economies of density by more efficiently using their physical branch networks. Recent articles have suggested that the Japanese bank mergers that occurred during 1999-2000 have largely failed. For example, The Economist (2000), noted that "Many of these [bank] mergers have been less than successful, essentially just lumping together banks without solving their underlying problems" (The Economist, 2000). Indeed, a recent Wall Street Journal (2004), in discussing the effects of the formation of the Mizuho Financial Group, noted that "Much of the initial motivation for the deal came not from the banks themselves, but from the government, which was pushing hard to consolidate Japans big lenders in the midst of a bad loan crisis . . . Artfully designed to look like a merger of equals, the chief executives of the three founding banks all shared that title in the new company, while three corporate units were run by executives from each of the founding companies. For three years, the banks even kept three computer systems run by three separate contractors" (Wall Street Journal, 2004).

It is unclear whether the megabanks intended to become operationally efficient when they were initially formed. This raises the question if these bank merger candidates had reason to believe at the time of the merger, that larger banks tended to be more efficient in the sense of having taken advantage of economies of scale and 
economies of density. The purpose of this study is to determine whether, as of 1998-1999 when the Japanese banking merger wave began, larger banks in Japan were more efficient than smaller banks and whether these efficiencies were mapped into higher profitability.

The issue is particularly important in the current Japanese banking landscape as the debate continues over whether bank mergers producing larger banks are beneficial because "bigger is better" or because there would be synergies from creating a larger bank which could lead to greater exploitation of economies of scale and economies of density. This was most recently seen during the fall of 2004 in the debate over whether UFJ (Japan's fourth largest bank) should be taken over by Sumitomo Mitsui (Japan's third largest bank) or Mitsubishi Tokyo (Japan's second largest bank). Regardless of which of the two banks combined with UFJ, the combined entity would be the world's largest lender (by assets), and would exceed both Citigroup (\$1.3 trillion) and the Mizuho Financial Group in size (the combined assets of UFJ-Sumitomo Mitsui would be $\$ 1.64$ trillion and the combined assets of UFJ - Mitsubishi-Tokyo would be $\$ 1.7$ trillion) (New York Times, 2004). The proposed merger between Mitsubishi Tokyo and UFJ highlights the idea that "bigger is better" - Mitsubishi Tokyo makes half of its loans to companies, while UFJ issues two-thirds of its loans to small and medium-sized companies and individuals. About three-quarters of Mitsubishi Tokyo's branches are in eastern Japan (including Tokyo), while two-thirds of UFJ's branches are in central and western Japan. There are few opportunities for reducing duplicative branches or pushing more products through underutilized branches to achieve economies of scale or density. Rather, the larger combined bank would be more likely to achieve greater revenues by adding the revenues from the disparate regions and client bases together (Barrons, 2004). On the other hand, the proposed merger between the Sumitomo Mitsui Group and UFJ highlights the possibility of achieving economies of scale and density since both banks are strong in retail and small business lending, and have branch networks in Osaka and Nagoya (The Economist, 2004). Underutilized branches can either be closed, or additional products can be pushed through them; duplicative branches can be reduced.

An understanding of the role of size and bank type on cost efficiency can assist in developing constructive strategies. A number of studies in the literature have examined cost efficiencies in the banking sectors in different geographic areas; surveys can be found in Saunders and Cornett (2002) and Berger and Humphrey (1997). Some examples of studies examining cost efficiencies in US and/or Canadian banks include: Benston et al. (1982), Kolari and Zardkoohi (1987), Doukas and Switzer (1991), McAllister and McManus (1993), Berger (1993), and Berger et al. (1997). Examples of studies examining cost efficiencies in European banks include: Fanjul and Maravall (1985), Rodriguez et al. (1993), Gathon and Grosjean (1991), McKillop et al. (1996), Zardkoohi and Kolari (1994), and Vander Vennet (1996).

There are few studies which focus on banking efficiency in Japan. McKillop et al. (1996) examined scale efficiencies for the five largest Japanese banks (city banks) during 1978-1991 and found increasing returns to scale during the period, and then constant returns from the late 1980s until 1991. Fukuyama (1993), using a cross-sectional dataset over 1990-1991, found constant returns to scale for the majority of the larger city banks. Nevertheless, Batchelor et al. (2000), using data during 1992-1998 found constant returns across all sizes of Japanese banks. Finally, 
IJMF

2,1
Altunbas et al. (2000) found evidence of diseconomies of scale for the larger Japanese banks. The results of this analysis, as will be discussed in the subsequent sections, suggest that large city banks exhibit diseconomies of scale, which is consistent with the hypothesis that, over time, as city banks became larger, they became less efficient.

This analysis examines the impact of size and bank type (city banks, trust banks, or regional banks) on cost-efficiency and profitability to determine whether larger banks were manifesting cost efficiencies at the time that the merger wave in Japanese banking started. The analysis differs from earlier studies in that it uses more recent data (1998-1999), emphasizes both bank type-specific and cross-sectional results to a greater degree than some of the other studies, and differentiates between economies of scale and economies of density.

The results of the analysis suggest that larger banks tend to be in the diseconomies region relative to smaller banks, which tend to be in the increasing returns region. This finding is supported not only by Japanese banking studies, but also by European studies. In Allen and Rai's (1996) cross-country piece on Europe, they found scale economies only for the smallest banks, with constant returns thereafter, and diseconomies for the largest bank. The European Commission (1997) used cross-sectional data on Europe and found increasing returns to scale for the small banks. Fanjul and Maravall (1985) and Rodriguez et al. (1993) did single country studies on Spain and found evidence of scale economies for medium-sized banks in Spain, and diseconomies for the larger institutions. Similarly, Gathon and Grosjean (1991) did a single country study for Belgium and found evidence of scale economies for small Belgian institutions and diseconomies of scale as size increased. Hensel (2003) cross-sectional analysis on European banking during 1998-1999 found similar results for banks in that smaller banks, especially regional banks, were in the increasing returns region. Unlike Japan, however, the largest European banks were in the constant returns region, rather than the decreasing returns region. The empirical findings in this study suggest that it is unlikely that the mega-mergers between large Japanese city banks were motivated by efficiencies from improved branch network utilization and rather may have been motivated by market power or a desire to become "too big to fail".

The paper is organized in several sections. Section 2 provides some background on the Japanese banking sector, discusses the data, and presents summary statistics on the various bank types. The model and methodology are developed in section 3, while section 4 describes the empirical findings and discusses the explanations behind them. Section 5 concludes by summarizing the main empirical findings and describing the various policy implications suggested by them.

\section{Background on the Japanese banking sector and data}

The Japanese banking sector[1] has traditionally been highly concentrated with high barriers to entry. At the beginning of the last decade, there were 21 "large" banks - 11 city banks, seven trust banks, and three long-term credit banks - which jointly controlled 73 percent of banking assets in Japan. By 2000, two had failed and/or been nationalized, and five of the remaining 17 banks had merged into two new entities (Friedman, 2000). The data, which are from OneSource Financial and Thomson/Polk's Banking Directory, consist of balance sheet, income statement, and cash flow measures for seven of the city banks, the 89 largest regional banks, and the six trust banks. 
These data cover the Japanese banking industry well because there were only nine city banks, 121 regional banks, and six trust banks as of 2000 .

Traditionally, the city banks served large corporations, rather than individual depositors, but as the financial markets developed as alternative sources of capital, city banks began servicing smaller companies and, in the 1980s, began expanding internationally. The city banks have extensive branch networks stretching throughout the country, although their name derives from their offices in all the major cities. The six trust banks do both banking and trust management (asset management). They have a strong metropolitan presence and an extensive corporate clientele. The 121 regional banks have branch networks concentrated in a particular prefecture and engage in relationship-lending to local small and medium-size businesses and local depositors. They lack the diversity of products, the extensive metropolitan presence, and the close relationships with large companies that the city banks and trust banks have. Regional banks tend to differentiate themselves through geographic location and spatial convenience, rather than through product diversity and hence are monopolistically competitive within their prefectures (depending on the degree of concentration). Trust banks and city banks, due to their smaller number, reflect a more oligopolistic market structure. The stronger regional banks have capital adequacy ratios equal to those of the city banks, and, unlike some of the larger city banks, have fewer public funds in their capital base. Regional banks have reduced exposure to the larger problem borrowers because they lend much less to them relative to the larger city banks (The Economist, 2002).

Basic summary statistics for the three types of banks and the overall sample are in Table I. On average, city banks, relative to trust banks and regional banks have the greatest number of employees and the greatest number of domestic and foreign offices. City banks have substantial volumes going through their branches and, consequently, high per branch profitability. For example, city banks have the highest value of deposits and loans per branch-deposits and loans per branch at city banks are five to six times higher than they are at regional banks. Due to their heavy involvement in asset management, trust banks have the highest value of investments per branch[2]. Sales per branch at city banks are eight times higher than at regional banks and net income per branch is 14 times greater than at regional banks[3].

The higher per branch volume of city banks and trust banks, relative to regional banks, results in higher overhead costs. City banks, closely followed by trust banks, have the most elaborate, and costly offices; indeed, property, plant, and equipment (PPE) per branch is almost five times greater at city banks than at regional banks, although they have only twice the number of employees per branch of regional banks, and about half the number of employees per branch for trust banks. Overhead expenses per employee for city banks and trust banks are almost twice those for regional banks. The high overhead expenses for city banks are a function of the diversity of products, corporate client emphasis, and, possibly, managerial inefficiencies. Regional banks have lower overhead costs which is a function of the simplicity of their traditional role[4].

\section{Methodology}

The model in this paper is based on a modified version of Jorgenson, Christensen, and Lau's translog cost function, a similar version of which appears in Caves et al. (1984). 


\section{IJMF \\ 2,1}

54

Number of banks

Output and infrastructure measures

Average number of employees

Average value of loans

Average value of deposits

Average value of investments

Average number of domestic offices

Average number of foreign offices

Average number of total offices

Branch office utilization measures

Average PPE per office

Average deposits per office

Average loans per office

Average investments per office

Average employees per office

Income and expenses per branch measures

Average non-interest expense per branch

Average sales per branch

Average net income per branch

Input prices

Average price of deposits (interest

expense/deposits)

Average price of loans (loan loss

provisions/loans)

Average price of overhead (overhead

expenses/employees)

Income and expense measures

Average interest expense

Average non-interest expense

Average loan loss provision

Average interest income

Commission and fee income (OBS activities)

\begin{tabular}{|c|c|c|c|}
\hline 3,112 & 13,455 & 2,190 & 4,391 \\
\hline 33,824 & 238,032 & 16,575 & 40,955 \\
\hline 35,977 & 24,290 & 19,724 & 38,509 \\
\hline 9,010 & 61,912 & 3,995 & 20,180 \\
\hline 125 & 315 & 114 & 65 \\
\hline 3 & 30 & 1 & 6 \\
\hline 128 & 345 & 115 & 71 \\
\hline 5.1985 & 16.846 & 3.5719 & 15.781 \\
\hline 214.31 & 688.32 & 156.14 & 529.48 \\
\hline 201.95 & 668.4 & 131.31 & 582.73 \\
\hline 56.632 & 177.07 & 31.112 & 275.08 \\
\hline 22.864 & 39.065 & 18.532 & 63.659 \\
\hline 4.650 & 13.95 & 2.969 & 18.38 \\
\hline 10.44 & 39.76 & 5.259 & 49.41 \\
\hline-2.369 & 13.95 & -0.580 & -22.63 \\
\hline 0.0111 & 0.0259 & 0.0069 & 0.03 \\
\hline 0.0138 & 0.0119 & 0.01223 & 0.03 \\
\hline 0.1768 & 0.3511 & 0.1564 & 0.28 \\
\hline 715.09 & 6,936 & 148.60 & $1,641.2$ \\
\hline 730.88 & $4,820.5$ & 370.01 & $1,317.6$ \\
\hline 478.93 & $3,003.3$ & 213.27 & $1,403.1$ \\
\hline $1,341.5$ & $10,927.3$ & 518.28 & $2,059.4$ \\
\hline 142.57 & $1,183.7$ & 53.653 & 248.37 \\
\hline
\end{tabular}

Table I.

Summary statistics for the entire sample and by bank type
Note: This Table shows the summary statistics for all the city banks, trust banks, and regional banks in the analysis during 1998-1999, the period covered by the study. The data, which are in millions of US dollars, are from the international database OneSource Financial, and come from the individual banks' income statements, balance-sheets, and cash flow statements, standardized by OneSource

The translog cost function has been used to estimate scale economies in a number of different banking studies, beginning with Benston et al. (1982)[5]. Examples of banking studies using the translog cost function to examine banking efficiency include: Doukas and Switzer's (1991) analysis of Canadian banks, Zardkoohi and Kolari's (1994) study on Finnish banks, and Pavlopoulos and Kouzelis (1989) analysis of Greek banks. This particular variant of the translog is different from other models in that it includes variables representing the branch network (number of branches), following Hensel 
(2003). This enables a distinction between economies of scale and economies of density, originally introduced in Caves et al.'s (1984) study on railroad productivity.

Economies of density are cost efficiencies from undertaking more transactions within a given branch network, holding the number of branches fixed, and measures the utilization of a branch network. Economies of scale are cost efficiencies from undertaking more transactions within a given branch network, and expanding the size of the network. These two measures help to determine whether a bank should undertake more transactions within its existing branch network (are there increasing returns to density?) or whether it should build more branches to undertake the greater volume of transactions (are there increasing returns to scale?)

This functional form provided several advantages over other methodologies. First, unlike the Cobb-Douglas function, it does not make assumptions involving constant returns to scale or input cost elasticities. Second, it provides point estimates of efficiency for each bank using cross-sectional data - parametric approaches such as thick frontier analysis would not provide estimates for particular banks, while distribution free analysis would provide estimates of average efficiency over time and could only be used for panel data, not cross-sectional data. Given the regulatory changes in the Japanese banking sector, as well as bank consolidation and failure, cross-sectional data was more appropriate for this period. Third, in parametric approaches such as stochastic frontier analysis, the more flexible the distributional assumptions placed on the inefficiency component of the error term for the specified cost function, the harder it is to disentangle the inefficiency component of the error term from the random error component of the error term. Fourth, nonparametric approaches, such as data envelope analysis, assume that there is no random component affecting the performance of the firm. A more full discussion of the various methodologies can be found in Goddard et al. (2001). Fifth, none of the alternative methodologies provide a distinction between density and scale measures of efficiency. Although, as discussed in McAllister and McManus (1993), the translog can have distortions away from the mean product mix in some datasets, its advantages for the purpose of this study are significant.

The basic form of the translog (equation 1) used in this analysis appears below with the input prices, outputs, and the variables representing the branch network (number of branches) entering linearly, quadratically, and interacted with each other. $Y$ represents output, $P$ represents the input price, $B$ represents the number of branches, and $S$ represents the share of the input cost in total cost. Equation 2 provides the functional form of the associated cost share equations, which are derived by differentiating the translog cost function by the natural log of price using Shepard's Lemma[6]:

$$
\begin{gathered}
\ln C=\ln \alpha_{0}+\sum_{i} \alpha_{i} \ln P_{i}+1 / 2^{*} \sum_{i} \sum_{j} \gamma_{i j} \ln P_{i} \ln P_{j}+\alpha_{Y} \\
\ln Y+1 / 2 \gamma_{Y Y}(\ln Y)^{2}+\sum_{i} \gamma_{i Y} \ln P \ln Y+\gamma_{B} \\
\ln B+1 / 2 \gamma_{B B}(\ln B)^{2}+\sum_{i} \gamma_{i B} \ln B^{*} \ln P_{i}+\gamma_{B Y} \ln B^{*} \ln Y \\
S_{i}=\alpha_{i}+\sum_{j} \gamma_{i j} \ln P_{j}+\gamma_{i Y} \ln Y+\gamma_{B Y} \ln B
\end{gathered}
$$


IJMF
2,1

56

The model used three outputs and three inputs. Loans, deposits, and investments were used as output $(Y)$ measures, thus following the "value-added" rather than the "intermediation" approach in including deposits as an output. This follows other banking efficiency estimation studies which used the "value-added" approach, such as Jagtiani and Khanthavit (1996) and Jagtiani et al. (1995). The likelihood ratio test between the unrestricted model including deposits and the restricted model without deposits confirmed the importance of deposit inclusion in modeling through the "value added" approach for this data - Chi2 (9) was 175.68 with a $p$-value of $0.0000[7]$. Inclusion of deposits as an output, and inclusion of the interest paid on deposits as an input cost (as will subsequently be discussed) recognizes the dual nature of deposits, which have both input and output characteristics, and follows other efficiency studies, such as Jagtiani and Khanthavit (1996), Jagtiani et al. (1995), Berger and Humphrey (1991), and Bauer et al. (1993). This modeling recognizes that deposits, as an output, are associated with various services provided by banks to depositors, involving aspects of payment, safe protection of depositor funds, and liquidity. Deposits have the characteristics of an input in that the funds raised through deposits enable banks to lend further, and in that banks pay for these funds through the interest on deposits received by customers[8].

Some output specifications in the banking efficiency literature have included off-balance sheet (OBS) items as an output. This analysis does not include OBS as an output because although a few of the large city banks and trust banks in the late 1990s were involved in OBS activities, most of the other banks in the sample were not. Using commissions and fee income as a proxy for OBS, the last line of Table I shows the low level of OBS activities relative to other sources of income during the period of the analysis across all three types of banks, as well as that the role of regional banks in OBS activities was very small - OBS activities were 22 times greater in city banks than regional banks and 4.6 times greater in the trust banks than the regional banks. When comparing the unrestricted model including OBS activities as an output, and the restricted model without OBS activities, the likelihood ratio test confirmed the unimportance of OBS inclusion in modeling - Chi2(10) was 10.14 with a p-value of 0.4279. Finally, the scale and density estimates generated using a model including OBS as an output were not significantly different from the estimates generated using a model excluding OBS.

The input costs - the $P^{\prime}$ s - included: the price of deposits (interest expense divided by deposits), the price of loans (loan loss provisions divided by loans), and the price of overhead (physical capital and salary expenses divided by employees). This is similar to the input price specifications used in other banking efficiency studies, such as Jagtiani and Khanthavit (1996), Jagtiani et al. (1995), and Schaffer (1993). The data did not allow for a more detailed breakdown of outputs or input prices; consequently, wages and PPE costs are combined into the price of overhead variable. The model also included branch variables, which were the sum of the total number of offices.

The basic translog cost function (equation 1) was estimated together with the associated cost share equations (equation 2 shows the functional form of the cost share equations) and symmetry and homogeneity conditions were imposed. To get a nonsingular system, one of the share equations was dropped, so the model was estimated using Zellner's iterated SUR methodology to obtain results which are asymptotically equivalent to maximum likelihood estimation, and hence invariant with respect to the share equation deleted. In addition, I ran Breusch-Pagan tests of independence for each model and verified the independence of the equations in the system. 
Following Caves et al. (1984), estimates of returns to density for total output are estimated as the sum of the elasticity of cost with respect to each output. When the sum of these elasticities is less than one, then there are increasing returns to density; when it is greater than one, then there are decreasing returns to density. Estimates of returns to scale for total output are estimated as the sum of not only the elasticity of cost with respect to each output, but also the elasticity of cost with respect to branch. This is because the number of branches is held fixed in density measurements, but allowed to vary in scale measurements.

The model does not include dummy variables for each type of bank because they did not improve the fit of the model. The likelihood ratio test of the model with city bank and trust bank dummies versus no dummies yielded a chi2 statistic of 1.17 , with a $p$-value of 0.5557 . The likelihood ratio test of the model with city bank and regional bank dummies versus no dummies yielded a chi2 statistic of 1.42 , with a p-value of 0.4914. The likelihood ratio test of the model with regional bank and trust bank dummies versus no dummies yielded a chi2 statistic of 1.30 , with a p-value of 0.5227 .

\section{Empirical findings}

The empirical evidence indicates that larger banks are more likely to have exhausted opportunities for scale and density efficiencies than smaller banks during 1998-1999, across the sample and within each bank type, immediately prior to the wave of mergers leading to the formation of megabanks. Point estimates of economies of scale and economies of density for each bank in the dataset were calculated using the parameter estimates from the estimated form of the translog cost function, which are in Table II. Table III shows the parameter estimates of the associated cost share equations, which were estimated together with the translog cost function.

The averages of the point estimates of economies of scale and economies of density for the sample overall and for each type of bank (city banks, trust banks, and regional banks) are found in Table IV. The overall sample of 103 banks exhibited increasing returns to scale and density, on average, indicating further opportunities to exploit cost efficiencies from pushing more output through the existing branch networks and from expanding the branch network. Nevertheless, this result was driven by the estimates for the 89 regional banks in the sample, which demonstrated substantial increasing returns to scale and density. The six trust banks on average experienced constant returns to scale and increasing returns to density; this suggests that they had underused capacity and could have achieved cost efficiencies by pushing more output through their existing branches, but that building new branches would not have generated further efficiencies, given the cost of opening new branches (refer to Table I) relative to the volumes. The seven city banks, many of whom were involved in merging with each other during the merger wave, exhibited substantial diseconomies of scale and density. This suggests that they had reached capacity within their existing branch networks (diseconomies of density), but that significant overhead costs of opening new branches and existing branches (refer to Table I) were yielding diseconomies of scale. City banks were inefficiently big prior to the merger wave, so it is not surprising that mergers between them have failed to yield efficiencies in the absence of branch consolidation. The result that the larger city banks on average were in the decreasing returns to scale region by 1998-1999 is consistent with the theory that city banks, as they became larger over time, became less efficient, as discussed in the literature review on Japanese banking studies in the introduction in section 1. 


\section{IJMF 2,1}

\begin{tabular}{|c|c|c|c|}
\hline Coefficient & Parameter estimate & Standard error & $p$-value \\
\hline $\ln$ (loans) & 0.3634 & 0.0540 & 0.000 \\
\hline $\ln$ (deposits) & 0.3849 & 0.0630 & 0.000 \\
\hline $\ln$ (investments) & 0.0827 & 0.0262 & 0.002 \\
\hline ln (branches) & 0.0741 & 0.0204 & 0.015 \\
\hline $\ln$ (price of deposits) & 0.2744 & 0.0030 & 0.000 \\
\hline $\ln$ (price of loans) & 0.3139 & 0.0047 & 0.000 \\
\hline $\ln$ (loans) * $\ln$ (deposits) & -0.1836 & 0.1159 & 0.113 \\
\hline $\ln$ (loans) * $\ln$ (investments) & 0.5146 & 0.1212 & 0.671 \\
\hline $\ln$ (deposits) * $\ln ($ investments) & -0.1401 & 0.2015 & 0.487 \\
\hline $\ln$ (loans) ${ }^{*} \ln$ (branches) & 0.2107 & 0.1310 & 0.108 \\
\hline ln (deposits) * $\ln ($ branches) & -0.1111 & 0.1893 & 0.557 \\
\hline $\ln$ (investments) *ln (branches) & -0.6656 & 0.0972 & 0.494 \\
\hline $\ln \left(\right.$ price of deposits) ${ }^{2}$ & 0.1708 & 0.0046 & 0.000 \\
\hline $\ln$ (price of loans) $^{2}$ & 0.1849 & 0.0040 & 0.000 \\
\hline $\ln (\text { loans) })^{2}$ & -0.0248 & 0.2202 & 0.910 \\
\hline $\ln \left(\right.$ deposits) ${ }^{2}$ & 0.5119 & 0.2188 & 0.019 \\
\hline $\ln \left(\right.$ investments) ${ }^{2}$ & 0.0965 & 0.0708 & 0.173 \\
\hline $\ln$ (branches) $^{2}$ & -0.1336 & 0.1126 & 0.235 \\
\hline $\ln$ (price of deposits) $* \ln$ (price of loans) & -0.0751 & 0.0126 & 0.000 \\
\hline $\ln$ (price of deposits) $* \ln$ (deposits) & 0.1502 & 0.0151 & 0.000 \\
\hline $\ln$ (price of deposits) $* \ln$ (investments) & -0.0179 & 0.0072 & 0.013 \\
\hline $\ln$ (price of deposits) $* \ln$ (loans) & -0.0564 & 0.0027 & 0.000 \\
\hline $\ln$ (price of loans) ${ }^{*} \ln$ (loans) & 0.0899 & 0.0155 & 0.000 \\
\hline $\ln$ (price of loans) ${ }^{*} \ln$ (deposits) & -0.0268 & 0.0204 & 0.189 \\
\hline $\ln$ (price of loans) $* \ln$ (investments) & -0.0260 & 0.0094 & 0.006 \\
\hline $\ln$ (price of deposits) $* \ln$ (branches) & -0.0139 & 0.0108 & 0.201 \\
\hline $\ln$ (price of loans) $* \ln$ (branches) & -0.0171 & 0.0151 & 0.257 \\
\hline Constant & -0.2522 & 0.0110 & 0.000 \\
\hline
\end{tabular}

Table II.

Translog cost function parameter estimates
Note: This Table shows the parameter estimates for the specified translog cost function used in this analysis. Estimates of returns to scale and returns to density are derived from these parameter estimates. Note that this translog cost function was estimated with its associated cost share equations, the parameter estimates of which are in Table III

The relationship between cost efficiencies (economies of scale and density) and various measures of profitability (and size) can be seen in the correlations between the point estimates of scale/density and assets, sales, and net income in Table V. The high positive correlations between scale/density and assets for the sample overall, and within each bank type suggest that larger banks, as measured by assets, are more likely to have higher scale and density estimates (i.e. are more likely to be in the constant or decreasing returns to scale and density region). The numbers in parenthesis are the $p$-values of significance tests, and indicate that all of these correlations are statistically signficant. Banks with higher sales are more likely to have higher scale and density estimates; again, this can be seen across the total sample, as well as within each bank type. The data suggest a negative relationship between net income and scale/density - i.e. more profitable banks (with a higher net income) are more likely to be exhibiting increasing returns to scale/density. This relationship is statistically significant for regional banks, but not for trust banks or city banks. 


\begin{tabular}{lrcr}
\hline Coefficient & Parameter estimate & Standard error & $P$-value \\
\hline First cost share equation: & & & \\
ln (loans) & -0.0751 & 0.0126 & 0.000 \\
ln (deposits) & 0.1502 & 0.0151 & 0.000 \\
ln (investments) & -0.0179 & 0.0072 & 0.013 \\
ln (branches) & -0.0139 & 0.0108 & 0.201 \\
ln (cost of deposits) & 0.1708 & 0.0046 & 0.000 \\
ln (cost of loans) & -0.0564 & 0.0027 & 0.000 \\
Constant & 0.2745 & 0.0030 & \\
Second cost share equation: & & & 0.000 \\
ln (loans) & 0.0899 & 0.0155 & 0.000 \\
ln (deposits) & -0.0268 & 0.0204 & 0.006 \\
ln (investments) & -0.0260 & 0.0094 & 0.257 \\
ln (branches) & -0.0171 & 0.0152 & 0.000 \\
ln (cost of deposits) & -0.0564 & 0.0027 & 0.000 \\
ln (cost of loans) & 0.1850 & 0.0041 & 0.000 \\
Constant & 0.3139 & 0.0042 &
\end{tabular}

Note: This Table shows the parameter estimates of the associated cost share equations, which were jointly estimated with the translog cost function in Table II. The parameter estimates for the translog cost function in Table II were then used to generate estimates of economies of scale and economies of density

\section{Japanese commercial banks}

59

Table III.

Parameter estimates of the cost share equations associated with the translog cost function

\begin{tabular}{llc}
\hline & Mean & Standard deviation \\
\hline Total sample returns to scale & 0.5035 & 0.5528 \\
Returns to density & 0.4083 & 0.6402 \\
City banks returns to scale & 1.8667 & 0.2685 \\
Returns to density & 1.972 & 0.3085 \\
Trust banks returns to scale & 0.9157 & 0.7034 \\
Returns to density & 0.6858 & 0.8201 \\
Regional banks returns to scale & 0.3659 & 0.3769 \\
Returns to density & 0.2667 & 0.4586
\end{tabular}

Note: This Table shows averages (and standard deviations) of the point estimates of returns to scale and returns to density for the overall sample, and for each type of bank (city banks, trust banks, and regional banks), using the parameter estimates from the translog cost function in Table II, which was estimated along with the cost share equations in Table III

Table IV.

Estimates of returns to scale and returns to density across bank types and within types

The relationship between cost efficiencies (economies of scale and density) and these measures of size and profitability (assets, sales, and net income) are estimated in a different way in Tables VI-VIII; the findings, however, confirm the statistically signficant positive relationship between assets and scale/density in Table V. Table VI estimates two models: the first model estimates economies of scale as a function of assets, dummy variables for each type of bank, and interaction terms between assets and the dummy variables. The specification in Table VI indicates a positive and statistically significant relation between assets and scale for all three types of banks - for trust banks, an increase in assets by 1 unit would increase the scale estimates by the sum of 


\section{IJMF \\ 2,1}

60

Table V.

Correlations of assets, sales, and net income with economies of scale and economies of density

\begin{tabular}{lcccccc}
\hline & \multicolumn{2}{c}{ Assets } & \multicolumn{2}{c}{ Sales } & \multicolumn{2}{c}{ Net income } \\
\hline Total sample $(n=103)$ scale & 0.782 & $(0.0000)$ & 0.758 & $(0.0000)$ & -0.675 & $(0.0000)$ \\
Density & 0.764 & $(0.0000)$ & 0.734 & $(0.0000)$ & -0.631 & $(0.0000)$ \\
City banks $(n=7)$ scale & 0.953 & $(0.0009)$ & 0.933 & $(0.0022)$ & -0.282 & $(0.5400)$ \\
Density & 0.934 & $(0.0020)$ & 0.903 & $(0.0054)$ & -0.294 & $(0.5218)$ \\
Regional banks $(n=89)$ scale & 0.913 & $(0.0000)$ & 0.843 & $(0.0000)$ & -0.321 & $(0.0022)$ \\
Density & 0.902 & $(0.0000)$ & 0.827 & $(0.0000)$ & -0.275 & $(0.0091)$ \\
Trust banks $(n=6)$ scale & 0.883 & $(0.0199)$ & 0.803 & $(0.0545)$ & -0.288 & $(0.5806)$ \\
Density & 0.841 & $(0.0358)$ & 0.764 & $(0.0768)$ & -0.212 & $(0.6862)$
\end{tabular}

Note: This Table shows the correlations of various measures of size (assets) and profitability (sales, net income) with estimates for returns to scale and returns to density. The $p$-values from significance tests for each of the correlations is in parentheses next to the correlation estimate and is in italics. The correlations between size/profitability with scale/density are done for the sample overall, then only for city banks, only for regional banks, and only for trust banks

\begin{tabular}{lcc}
\hline & $\begin{array}{c}\text { Model I } \\
\text { Parameter estimate } \\
\text { (Standard error) } \\
p \text {-value }\end{array}$ & $\begin{array}{c}\text { Model II } \\
\text { Parameter estimate } \\
\text { (Standard error) } \\
p \text {-value }\end{array}$ \\
\hline Constant & 0.9853 & 0.8432 \\
& $(0.1393)$ & $(0.1854)$ \\
Assets & $p=0.000$ & $p=0.000$ \\
& $2.23 \mathrm{e}-06$ & $2.81 \mathrm{e}-06$ \\
Trust bank dummy & $(3.74 \mathrm{e}-07)$ & $(4.98 \mathrm{e}-07)$ \\
& $p=0.000$ & $p=0.000$ \\
Regional bank dummy & -0.9737 & -1.1623 \\
& $(0.1949)$ & $(0.2595)$ \\
Assets * trust bank & -1.0921 & -1.1448 \\
& $(0.1429)$ & $(0.1902)$ \\
Assets * regional bank & $1.03 \mathrm{e}-05$ & $1.11 \mathrm{e}-05$ \\
& $(1.65 \mathrm{e}-06)$ & $(2.19 \mathrm{e}-06)$ \\
& $p=0.000$ & $2.28 \mathrm{e}-05$ \\
& $(1.91 \mathrm{e}-05$ & $(1.64 \mathrm{e}-06)$
\end{tabular}

Notes: This Table estimates returns to scale as a function of assets, dummy variables for each type of bank, and interaction terms between assets and bank-type dummy variables (model I) and estimates returns to density as a function of the same variables (model II). Parameter estimates for each coefficient are shown, along with their standard error in parentheses and $p$-value. The regression specification provides an alternative method to using the correlations in Table $\mathrm{V}$ to determine the relationship between scale efficiencies/density efficiencies and size, within each bank type and across bank types. Model I: Estimate of returns to scale $=\alpha+\beta_{1}$ (assets) $+\beta_{2}$ (trust bank) $+\beta_{3}$ (regional bank $)+\beta_{4}$ (assets * trust bank) $+\beta_{5}$ (assets* regional bank). Adj $R$-square: 0.8970. Model II: Estimate of returns to density $=\alpha+\beta_{1}$ (assets) $+\beta_{2}$ (trust bank) $+\beta_{3}$ (regional bank) $+\beta_{4}$ (assets $*$ trust bank) $+\beta_{5}$ (assets* regional bank). Adj. $R$-square: 0.8639

Table VI.

Regressions of economies of scale and density on assets, sales, and net income 


\begin{tabular}{|c|c|c|}
\hline Coefficient & $\begin{array}{c}\text { Model III } \\
\text { Parameter estimate } \\
\text { (Standard error) } \\
p \text {-value }\end{array}$ & $\begin{array}{c}\text { Model IV } \\
\text { Parameter estimate } \\
\text { (Standard error) } \\
p \text {-value }\end{array}$ \\
\hline \multirow[t]{2}{*}{ Constant } & $\begin{array}{c}1.1208 \\
(0.1551)\end{array}$ & $\begin{array}{c}1.0197 \\
(0.2007)\end{array}$ \\
\hline & $p=0.000$ & $p=0.000$ \\
\hline \multirow[t]{2}{*}{ Sales } & $\begin{array}{r}4.7 \mathrm{e}-05 \\
(0.0000)\end{array}$ & $\begin{array}{c}5.87 \mathrm{e}-05 \\
(0.0000)\end{array}$ \\
\hline & $p=0.000$ & $p=0.000$ \\
\hline \multirow[t]{2}{*}{ Trust bank dummy } & $\begin{array}{r}-0.8679 \\
(0.2163)\end{array}$ & $\begin{array}{r}-1.0696 \\
(0.2799)\end{array}$ \\
\hline & $p=0.000$ & $p=0.000$ \\
\hline \multirow[t]{2}{*}{ Regional bank dummy } & $\begin{array}{r}-1.1541 \\
(0.1599)\end{array}$ & $\begin{array}{r}-1.2297 \\
(0.2069)\end{array}$ \\
\hline & $p=0.000$ & $p=0.000$ \\
\hline \multirow[t]{2}{*}{ Sales * trust bank } & $\begin{array}{l}1.36 \mathrm{e}-05 \\
(0.0000)\end{array}$ & $\begin{array}{c}1.45 \mathrm{e}-05 \\
(0.0000)\end{array}$ \\
\hline & $p=0.000$ & $p=0.000$ \\
\hline \multirow[t]{2}{*}{ Sales * regional bank } & $\begin{array}{c}5.51 \mathrm{e}-04 \\
(0.0000)\end{array}$ & $\begin{array}{c}6.56 \mathrm{e}-04 \\
(0.0000)\end{array}$ \\
\hline & $p=0.000$ & $p=0.000$ \\
\hline
\end{tabular}

Notes: This Table estimates returns to scale as a function of sales, dummy variables for each type of bank, and interaction terms between sales and bank-type dummy variables (model III) and estimates returns to density as a function of the same variables (model IV). Parameter estimates for each coefficient are shown, along with their standard error in parentheses and $p$-value. The regression specification provides an alternative method to using the correlations in Table $\mathrm{V}$ to determine the relationship between scale efficiencies/density efficiencies and profitability, within each bank type and across bank types. Model III: Estimate of returns to scale $=\alpha+\beta_{1}$ (sales) $+\beta_{2}$ (trust bank) $+\beta_{3}$ $($ regional bank $)+\beta_{4}$ (sales * trust bank) $+\beta_{5}$ (sales * regional bank). Adj $R$-square: 0.8319. Model IV: Estimate of returns to density $=\alpha+\beta_{1}$ (sales) $+\beta_{2}$ (trust bank) $+\beta_{3}$ (regional bank) $+\beta_{4}$ (sales * trust bank) $+\beta_{5}$ (sales * regional bank). Adj. $R$-square: 0.7902

\section{Japanese commercial banks}

61

Table VII.

Regressions of economies of scale and density on assets, sales, and net income

the coefficient for assets (2.23e-06) and the coefficient for the interaction term between trust banks and assets (1.03e-05); for regional banks, the increase in scale estimates would be the sum of the coefficient for assets $(2.23 \mathrm{e}-06)$ and the coefficient of the interaction term between assets and regional banks (1.91e-05); for city banks, the increase in scale estimates would be just the coefficient on assets. The second model estimates economies of density as a function of the same variables and finds similar results.

The relationship between size and efficiency is not surprising. Density economies are more likely to be exhausted on the margin for larger banks because larger banks process more transactions than smaller banks precisely because they are larger, so their branch network is more likely to have reached capacity, holding the number of branches fixed[9]. Diseconomies of density may occur because of congestion at branches. For example, as the demand for loans increases, the resources of the existing branch facilities and loan officers can become sufficiently strained such that in-depth credit analyses are not possible; as a result, more bad loans are made, which increases the input cost of a loan - the loan loss provisions - and lowers returns to density in loans. 


\section{IJMF 2,1}

\begin{tabular}{|c|c|c|}
\hline Coefficient & $\begin{array}{c}\text { Model V } \\
\text { Parameter estimate } \\
\text { (Standard error) } \\
p \text {-value }\end{array}$ & $\begin{array}{c}\text { Model VI } \\
\text { Parameter estimate } \\
\text { (Standard error) } \\
p \text {-value }\end{array}$ \\
\hline \multirow[t]{2}{*}{ Constant } & $\begin{array}{c}1.3114 \\
(0.2629)\end{array}$ & $\begin{array}{l}1.2129 \\
(0.3247)\end{array}$ \\
\hline & $p=0.000$ & $p=0.000$ \\
\hline \multirow[t]{2}{*}{ Net income } & $\begin{array}{c}-1.78 \mathrm{e}-04 \\
(0.0001)\end{array}$ & $\begin{array}{c}-2.42 \mathrm{e}-04 \\
(0.0001)\end{array}$ \\
\hline & $p=0.068$ & $p=0.045$ \\
\hline \multirow[t]{2}{*}{ Trust bank dummy } & $\begin{array}{r}-0.6745 \\
(0.3886)\end{array}$ & $\begin{array}{r}-0.7673 \\
(0.4798)\end{array}$ \\
\hline & $p=0.086$ & $p=0.113$ \\
\hline \multirow[t]{2}{*}{ Regional bank dummy } & $\begin{array}{r}-0.9918 \\
(0.2666)\end{array}$ & $\begin{array}{r}-0.9945 \\
(0.3291)\end{array}$ \\
\hline & $p=0.000$ & $p=0.003$ \\
\hline Net income ${ }^{*}$ trust bank & $\begin{array}{c}-3.43 \mathrm{e}-05 \\
(0.0002)\end{array}$ & $\begin{array}{l}\text { 5.87e-05 } \\
\text { (0.0003) }\end{array}$ \\
\hline Net income * regional bank & $\begin{aligned} p=0.868 \\
-5.19 \mathrm{e}-05 \\
(0.0003) \\
0.046 p=0.129\end{aligned}$ & $\begin{array}{c}p=0.818 \\
-4.86 \mathrm{e}-04 \\
\quad(0.0003)\end{array}$ \\
\hline
\end{tabular}

Table VIII.

Regressions of economies of scale and density on assets, sales, and net income
Notes: This Table estimates returns to scale as a function of net income, dummy variables for each type of bank, and interaction terms between net income and bank-type dummy variables (model V) and estimates returns to density as a function of the same variables (model VI). Parameter estimates for each coefficient are shown, along with their standard error in parentheses and $p$-value. The regression specification provides an alternative method to using the correlations in Table $\mathrm{V}$ to determine the relationship between scale/density efficiencies and profitability, within each bank type and across bank types. Model V: Estimate of returns to scale $=\alpha+\beta_{1}$ (net income) $+\beta_{2}$ (trust bank) $+\beta_{3}$ (regional bank) $+\beta_{4}$ (net income ${ }^{*}$ trust bank) $+\beta_{5}$ (net income ${ }^{*}$ regional bank). Adj $R$-square: 0.5103. Model VI: Estimate of returns to density $=\alpha+\beta_{1}$ (net income) $+\beta_{2}$ (trust bank) $+\beta_{3}$ (regional bank) $+\beta_{4}$ (net income ${ }^{*}$ trust bank) $+\beta_{5}$ (net income ${ }^{*}$ regional bank). Adj. $R$-square: 0.4433

Scale economies are more likely to be exhausted on the margin for larger banks for several reasons. First, larger banks can exhibit managerial diseconomies (discussed in Williamson (1967), Williamson (1970), and Keren and Levhari (1983)) because they have more layers of management than smaller banks. Second, the overhead costs for larger banks for opening up a new branch can be higher for larger banks than smaller banks. Larger banks often compete on non-price aspects, such as knowledgeability of staff, and are often located in more metropolitan areas with higher rents. As a result, the overhead costs and labor costs are higher for larger banks because the branches are staffed by more skilled employees and are more elaborate. Consequently, the cost-structure is less favorable for opening a new branch - constant or decreasing returns to scale - because overhead costs are higher[10]. This is supported by the summary statistics on PPE per branch, overhead expenses per branch, non-interest expense per branch, etc. in Table I for larger city banks, which exhibit diseconomies of scale relative to smaller regional banks.

Smaller regional banks are more likely to be in the increasing returns to density region, with underutilized networks, than city banks. This may be due to a greater emphasis by 
regional banks on spatial convenience within their prefecture - "a branch at every corner". In addition, some of the regional markets are thinner and generate less volume than metropolitan markets, in which city banks and trust banks are located. This results in a dense network of underutilized branches. Although regional banks do not have more branches than city banks or trust banks, they often have more branches relative to the volumes that they process, as the summary statistics in tTable 1 on low per branch volumes for regional banks, relative to city banks and trust banks, indicate[11].

The finding that banks with high sales are more likely to have exploited scale and density efficiencies is reinforced by the findings in Table VII, which estimate economies of scale and economies of density, respectively (models III and IV), as a function of sales, dummy variables for each type of bank, and interaction terms between the dummy variables for each type of bank and sales[12]. Banks with high sales are more likely to have exploited scale and density efficiencies because, in order to achieve high sales, banks may undertake a greater volume of transactions within their existing branch network, leading to diseconomies of density and branch congestion. The banks which have higher sales also are more likely to be city banks, which have high overhead costs for opening up another branch, leading to diseconomies of scale when the marginal increase in value of the additional transactions which could be processed by another branch is exceeded by the marginal cost of opening up a new branch. Hensel (2003), which examined the relationship between sales and scale/density efficiencies for European banks during 1998-1999, found similar results.

As was evident in the negative correlations between net income and scale/density in Table $\mathrm{V}$, banks with high net incomes are more likely to be in the increasing returns region. This negative relationship is reinforced by the findings in Table VIII, which estimate economies of scale and economies of density, respectively (model $\mathrm{V}$ and model VI), as a function of net income, dummy variables for each type of bank, and interaction terms between the dummy variables for each type of bank and net income[13]. In Table $\mathrm{V}$, the negative relationships were not statistically significant for city banks and trust banks, although they were for regional banks. Table VIII also indicates that the relationship between net income and scale/density is not statistically significant for all types of banks, although the relationship between net income and scale is significant at the 10 percent level for city banks and regional banks and the relationship between net income and density is significant at the 5 percent level for city banks. The explanation for this negative relationship between net income and scale/density may be that the larger Japanese banks, especially city banks, exhibited diseconomies of scale/density, and the resulting diseconomies on the cost-side of undertaking more transactions outweighed the benefit of greater revenue/sales from undertaking more transactions, leading to lower net incomes (revenue minus costs) for larger banks. This differs from the finding for European banks during 1998-1999 of Hensel (2003), which found a positive relationship between net income and scale/density, rather than a negative relationship. This is because the larger European banks exhibited constant returns to scale/density, not decreasing returns as the Japanese banks did.

The positive and largely statistically significant correlations between scale/density estimates, and various measures of size - the value of loans, deposits, investments, and the number of branches, and employees - for the total sample and for each type of bank can be found in Table IX. Banks which have a greater value of loans, deposits, 
IJMF
2,1

64

Table IX.

Correlations between

loans, deposits,

investments, branches, and economies of

scale/density

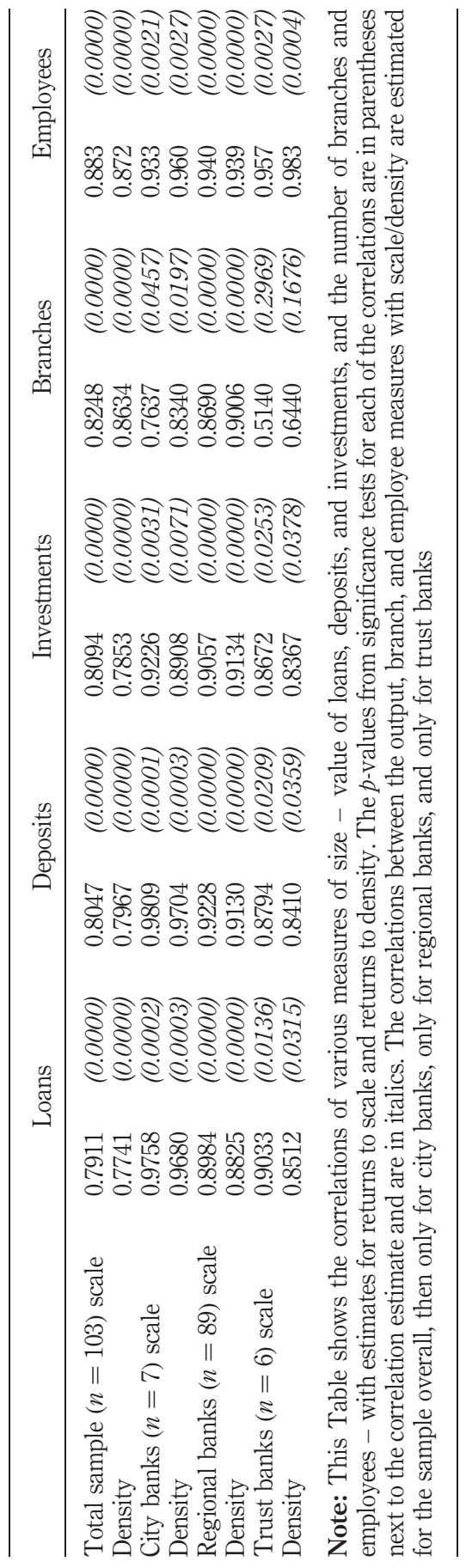


and investments going through their branch network, as well as banks with more branches and more employees, are more likely to be in the constant to decreasing returns to scale and density region. This is probably because banks with more branches and employees often have a large volume of transactions going through them and consequently tend to be more likely to have exhausted further opportunities for cost efficiencies within their networks, holding the size of the network fixed. Since these banks also tend to be larger banks with higher overhead costs, the cost of opening up another branch is higher, which contributes to diseconomies of scale. The empirical evidence in Tables X-XIV largely reinforce this finding and indicate a positive and statistically significant relationship between each measure of size and scale/density[14] (see Tables IX-XIV).

\section{Conclusion}

This paper examines whether Japanese banks (city banks, trust banks, and regional banks) exhibited cost efficiencies - economies of scale and economies of densitywithin their branch networks, the relationship between various measures of size and

\begin{tabular}{|c|c|c|}
\hline Coefficient & $\begin{array}{c}\text { Model VII } \\
\text { Parameter estimate } \\
\text { (Standard error) } \\
p \text {-value }\end{array}$ & $\begin{array}{c}\text { Model VIII } \\
\text { Parameter estimate } \\
\text { (Standard error) } \\
p \text {-value }\end{array}$ \\
\hline Constant & $\begin{array}{r}0.9016 \\
(0.1573) \\
p=0.000\end{array}$ & $\begin{array}{r}0.7357 \\
(0.2123) \\
p=0.001\end{array}$ \\
\hline Trust bank dummy & $\begin{array}{r}p=0.000 \\
-0.9413 \\
(0.2138) \\
h=0.000\end{array}$ & $\begin{array}{c}p=0.000 \\
-1.100 \\
(0.2886) \\
p=0.000\end{array}$ \\
\hline Regional bank dummy & $\begin{array}{c}(0.1607) \\
p=0.000\end{array}$ & $\begin{array}{c}-1.0223 \\
(0.2170) \\
p=0.000\end{array}$ \\
\hline Loans * trust bank & $p=0.000$ & $p=0.000$ \\
\hline Loans * regional bank & $\begin{array}{c}2.42 \mathrm{e}-05 \\
(1.74 \mathrm{e}-06) \\
p=0.000\end{array}$ & $\begin{array}{c}2.87 \mathrm{e}-05 \\
(2.35 \mathrm{e}-06) \\
p=0.000\end{array}$ \\
\hline
\end{tabular}

Notes: This Table estimates returns to scale as a function of loans, dummy variables for each type of bank, and interaction terms between loans and bank-type dummy variables (model VII) and estimates returns to density as a function of the same variables (model VIII). Parameter estimates for each coefficient are shown, along with their standard error in parentheses and $p$-value. The regression specification provides an alternative method to using the correlations in Table IX to determine the relationship between scale efficiencies/density efficiencies and size, within each bank type and across bank types. Model VII: Estimate of returns to scale $=\alpha+\beta_{1}$ (loans) $+\beta_{2}$ (trust bank) $+\beta_{3}$ (regional bank) $+\beta_{4}$ (loans $*$ trust bank) $+\beta_{5}$ (loans $*$ regional bank). Adj $R$-square: 0.8891 . Model VIII: Estimate of returns to density $=\alpha+\beta_{1}$ (loans) $+\beta_{2}$ (trust bank) $+\beta_{3}$ (regional bank) $+\beta_{4}$ (loans ${ }^{*}$ trust bank) $+\beta_{5}$ (loans ${ }^{*}$ regional bank). Adj. $R$-square: 0.8494

Table X.

Regressions of economies of scale and density on loans, deposits, investments, branches 


\section{IJMF 2,1}

\begin{tabular}{|c|c|c|}
\hline Coefficient & $\begin{array}{c}\text { Model IX } \\
\text { Parameter estimate } \\
\text { (Standard error) } \\
p \text {-value }\end{array}$ & $\begin{array}{c}\text { Model X } \\
\text { Parameter estimate } \\
\text { (Standard error) } \\
p \text {-value }\end{array}$ \\
\hline \multirow[t]{2}{*}{ Constant } & $\begin{array}{c}0.9287 \\
(0.1240)\end{array}$ & $\begin{array}{c}0.7450 \\
(0.1641)\end{array}$ \\
\hline & $p=0.000$ & $p=0.000$ \\
\hline \multirow[t]{2}{*}{ Deposits } & $\begin{array}{c}3.71 \mathrm{e}-06 \\
(5.11 \mathrm{e}-07)\end{array}$ & $\begin{array}{r}4.79 \mathrm{e}-06 \\
(6.76 \mathrm{e}-07)\end{array}$ \\
\hline & $p=0.000$ & $p=0.000$ \\
\hline \multirow[t]{2}{*}{ Trust bank dummy } & $\begin{array}{r}-0.8080 \\
(0.1689)\end{array}$ & $\begin{array}{r}-0.9456 \\
(0.2235)\end{array}$ \\
\hline & $p=0.000$ & $p=0.000$ \\
\hline \multirow[t]{2}{*}{ Regional bank dummy } & $\begin{array}{r}-1.0534 \\
(0.1276)\end{array}$ & $\begin{array}{c}-1.069 \\
(0.1688)\end{array}$ \\
\hline & $p=0.000$ & $p=0.000$ \\
\hline \multirow[t]{2}{*}{ Deposits * trust bank } & $\begin{array}{r}1.69 \mathrm{e}-05 \\
(2.48 \mathrm{e}-06)\end{array}$ & $\begin{array}{r}1.82 \mathrm{e}-05 \\
(3.28 \mathrm{e}-06)\end{array}$ \\
\hline & $p=0.000$ & $p=0.000$ \\
\hline Deposits ${ }^{*}$ regional bank & $\begin{array}{c}2.12 \mathrm{e}-05 \\
(1.34 \mathrm{e}-06) \\
p=0.000\end{array}$ & $\begin{array}{r}2.52 \mathrm{e}-05 \\
(1.78 \mathrm{e}-06) \\
p=0.000\end{array}$ \\
\hline
\end{tabular}

Notes: This Table estimates returns to scale as a function of deposits, dummy variables for each type of bank, and interaction terms between deposits and bank-type dummy variables (model IX) and estimates returns to density as a function of the same variables (model X). Parameter estimates for each coefficient are shown, along with their standard error in parentheses and $p$-value. The regression specification provides an alternative method to using the correlations in Table IX to determine the relationship between scale/density efficiencies and size, within each bank type and across bank types.

Table XI.

Regressions of economies of scale and density on loans, deposits, investments, branches
Model IX: Estimate of returns to scale $=\alpha+\beta_{1}$ (deposits) $+\beta_{2}$ (trust bank) $+\beta_{3}$ (regional bank) $+\beta_{4}$ (deposits * trust bank) $+\beta_{5}$ (deposits * regional bank). Adj $R$-square: 0.8891 . Model X: Estimate of returns to density $=\alpha+\beta_{1}$ (deposits) $+\beta_{2}$ (trust bank) $+\beta_{3}$ (regional bank) $+\beta_{4}$ (deposits * trust bank $)+\beta_{5}$ (deposits ${ }^{*}$ regional bank). Adj. $R$-square: 0.8494

cost efficiencies, and the policy implications of the findings. The study estimates economies of scale and density in the Japanese banking sector during 1998-1999, at the beginning of the merger wave between large Japanese banks. Since this merger wave has not yielded efficiencies, but rather has yielded opportunities for exercise of market power and for creation of an entity which is "too big to fail," this analysis sheds light on whether, at the start of the wave, banks had reason to believe that larger banks were more efficient than smaller banks in Japan.

Several key results emerge from the analysis. First, the data suggest that city banks, which tended to merge with each other during the ensuing merger wave, on average, exhibited significant diseconomies of scale and density at the time that the merger wave started. Trust banks, on average, exhibited constant returns to scale and increasing returns to density, and regional banks experienced substantial increasing returns to scale and density (Table IV). Second, larger banks (as measured by assets, value of loans, value of deposits, value of investments, number of employees, and number of branches) were more likely to be in the decreasing returns to scale/density or constant returns to scale/density region than smaller banks. This finding was 


\begin{tabular}{|c|c|c|}
\hline Coefficient & $\begin{array}{c}\text { Model XI } \\
\text { Parameter estimate } \\
\text { (Standard error) } \\
p \text {-value }\end{array}$ & $\begin{array}{c}\text { Model XII } \\
\text { Parameter estimate } \\
\text { (Standard error) } \\
p \text {-value }\end{array}$ \\
\hline \multirow[t]{2}{*}{ Constant } & $\begin{array}{c}0.9823 \\
(0.1444)\end{array}$ & $\begin{array}{c}0.8401 \\
(0.1791)\end{array}$ \\
\hline & $p=0.000$ & $p=0.000$ \\
\hline \multirow[t]{2}{*}{ Investments } & $\begin{array}{r}1.32 \mathrm{e}-05 \\
(2.28 \mathrm{e}-06)\end{array}$ & $\begin{array}{r}1.66 \mathrm{e}-05 \\
(2.83 \mathrm{e}-06)\end{array}$ \\
\hline & $p=0.000$ & $p=0.000$ \\
\hline \multirow[t]{2}{*}{ Trust bank dummy } & $\begin{array}{r}-0.8651 \\
(0.1951)\end{array}$ & $\begin{array}{r}-1.0525 \\
(0.2421)\end{array}$ \\
\hline & $p=0.000$ & $p=0.000$ \\
\hline \multirow[t]{2}{*}{ Regional bank dummy } & $\begin{array}{c}-1.070 \\
(0.1480)\end{array}$ & $\begin{array}{r}-1.1301 \\
(0.1836)\end{array}$ \\
\hline & $p=0.000$ & $p=0.000$ \\
\hline \multirow[t]{2}{*}{ Investments * trust bank } & $\begin{array}{r}2.64 \mathrm{e}-05 \\
(5.80 \mathrm{e}-06)\end{array}$ & $\begin{array}{r}2.79 \mathrm{e}-05 \\
(7.20 \mathrm{e}-06)\end{array}$ \\
\hline & $p=0.000$ & $p=0.000$ \\
\hline Investments ${ }^{*}$ regional bank & $\begin{array}{c}1.004 \mathrm{e}-05 \\
(6.91 \mathrm{e}-06)\end{array}$ & $\begin{array}{c}1.23 \mathrm{e}-05 \\
(8.57 \mathrm{e}-06)\end{array}$ \\
\hline
\end{tabular}

Notes: This Table estimates returns to scale as a function of investments, dummy variables for each type of bank, and interaction terms between investments and bank-type dummy variables (model XI) and estimates returns to density as a function of the same variables (model XII). Parameter estimates for each coefficient are shown, along with their standard error in parentheses and $p$-value. The regression specification provides an alternative method to using the correlations in Table IX to determine the relationship between scale/density efficiencies and size, within each bank type and across bank types. Model XI: Estimate of returns to scale $=\alpha+\beta_{1}$ (investments) $+\beta_{2}$ (trust bank) $+\beta_{3}$ (regional bank) $+\beta_{4}$ (investments ${ }^{*}$ trust bank) $+\beta_{5}$ (investments ${ }^{*}$ regional bank). Adj $R$-square: 0.8894. Model XII: Estimate of returns to density $=\alpha+\beta_{1}$ (investments) $+\beta_{2}$ (trust bank) $+\beta_{3}$ (regional bank) $+\beta_{4}$ (investments * trust bank) $+z ; \beta_{5}$ (investments ${ }^{*}$ regional bank). Adj. $R$-square: 0.8730

\section{Japanese commercial banks}

67

Table XII.

Regressions of economies of scale and density on loans, deposits, investments, branches

statistically significant within each type of bank (city banks, regional banks, and trust banks) and across the types of banks. This is consistent with the findings of earlier studies on the Japanese banking system, as well as other studies on the banking sector in the US and in Europe. Third, banks with higher sales were more likely to be in the constant/decreasing returns to density/scale region. This finding was statistically significant for all three types of banks (city banks, regional banks, and trust banks) and across the types of banks. Fourth, banks with higher net incomes, however, were more likely to be in the increasing returns to scale/density region. The relationship was not significant for trust banks, but it was significant at either the 5 percent level or the 10 percent level for city banks and regional banks.

The empirical evidence on the relationship between size and efficiency suggests that at the time that the megabank merger wave started, there was little evidence that bigger banks were more efficient. This, in turn, raises questions concerning the motivations of the large Japanese city banks in merging and supports the hypothesis that they may have been seeking opportunities to exercise greater market power or to 


\section{IJMF 2,1}

\begin{tabular}{|c|c|c|}
\hline Coefficient & $\begin{array}{c}\text { Model XIII } \\
\text { Parameter estimate } \\
\text { (Standard error) } \\
p \text {-value }\end{array}$ & $\begin{array}{c}\text { Model XIV } \\
\text { Parameter estimate } \\
\text { (Standard error) } \\
p \text {-value }\end{array}$ \\
\hline \multirow[t]{2}{*}{ Constant } & $\begin{array}{c}0.5715 \\
(0.2518)\end{array}$ & $\begin{array}{c}0.2087 \\
(0.2692)\end{array}$ \\
\hline & $p=0.025$ & $p=0.440$ \\
\hline \multirow[t]{2}{*}{ Total offices } & $\begin{array}{c}0.0037 \\
(0.0008)\end{array}$ & $\begin{array}{c}0.0050 \\
(0.0008)\end{array}$ \\
\hline & $p=0.000$ & $p=0.000$ \\
\hline \multirow[t]{2}{*}{ Trust bank dummy } & $\begin{array}{r}-0.4477 \\
(0.3514)\end{array}$ & $\begin{array}{r}-0.6796 \\
(0.3757)\end{array}$ \\
\hline & $p=0.206$ & $p=0.074$ \\
\hline \multirow[t]{2}{*}{ Regional bank dummy } & $\begin{array}{r}-1.0615 \\
(0.2610)\end{array}$ & $\begin{array}{r}-1.0212 \\
(0.2791)\end{array}$ \\
\hline & $p=0.000$ & $p=0.000$ \\
\hline \multirow[t]{2}{*}{ Total offices ${ }^{*}$ trust bank } & $\begin{array}{c}0.0074 \\
(0.0033)\end{array}$ & $\begin{array}{c}0.0112 \\
(0.0035)\end{array}$ \\
\hline & $p=0.025$ & $p=0.002$ \\
\hline Total offices * regional bank & $\begin{array}{c}0.0038 \\
(0.0009)\end{array}$ & $\begin{array}{c}0.0044 \\
(0.0010)\end{array}$ \\
\hline
\end{tabular}

Notes: This Table estimates returns to scale as a function of total offices, dummy variables for each type of bank, and interaction terms between total offices and bank-type dummy variables (model XIII) and estimates returns to density as a function of the same variables (model XIV). Parameter estimates for each coefficient are shown, along with their standard error in parentheses and $p$-value. The regression specification provides an alternative method to using the correlations in Table IX to determine the relationship between scale/density efficiencies and size, within each bank type and across bank types.

Table XIII.

Regressions of economies of scale and density on loans, deposits, investments, branches
Model XIII: Estimate of returns to scale $=\alpha+\beta_{1}$ (total offices) $+\beta_{2}$ (trust bank) $+\beta_{3}$ (regional bank) $+\beta_{4}$ (total offices ${ }^{*}$ trust bank) $+\beta_{5}$ (total offices ${ }^{*}$ regional bank). Adj $R$-square: 0.8894. Model XIV: Estimate of returns to density $=\alpha+\beta_{1}$ (total offices) $+\beta_{2}$ (trust bank) $+\beta_{3}$ (regional bank) $+\beta_{4}$ (total offices ${ }^{*}$ trust bank) $+\beta_{5}$ (total offices ${ }^{*}$ regional bank). Adj. $R$-square: 0.8730

create an entity which was "too big to fail". Indeed, the press at the time was concerned in many cases that the rationale for efficiency from the mergers was weak, but that the rationale for greater market power was believable. Subsequent events have shown that efficiencies have not materialized.

It is not surprising that the mega-mergers were between large city banks, which were in the diseconomies region in scale/density did not yield efficiencies. Possibly, mergers between city banks and regional banks (which were in the increasing returns to scale and density region), or city banks and trust banks (which were in the constant/increasing returns to scale and density region) would have led to greater efficiencies in terms of exploitation of efficiencies through more efficient utilization of underutilzed branch networks.

Mergers between city banks and regional banks may have yielded efficiencies through greater utilization of underutilized regional banking branch networks. Since regional banks exhibited increasing returns to density and have low costs for opening up another branch (as seen in their increasing returns to scale estimates and in the summary statistics on their low overhead costs), they could take advantage of cost 


\begin{tabular}{|c|c|c|}
\hline Coefficient & $\begin{array}{c}\text { Model XVII } \\
\text { Parameter estimate } \\
\text { (Standard error) } \\
p \text {-value }\end{array}$ & $\begin{array}{c}\text { Model XVIII } \\
\text { Parameter estimate } \\
\text { (Standard error) } \\
p \text {-value }\end{array}$ \\
\hline \multirow[t]{2}{*}{ Constant } & $\begin{array}{c}0.4639 \\
(0.1575)\end{array}$ & $\begin{array}{c}0.1147 \\
(0.1903)\end{array}$ \\
\hline & $p=0.004$ & $p=0.548$ \\
\hline \multirow[t]{2}{*}{ Employees } & $\begin{array}{l}1.02 \mathrm{e}-04 \\
(0.0000)\end{array}$ & $\begin{array}{l}1.34 \mathrm{e}-04 \\
(0.0000)\end{array}$ \\
\hline & $p=0.000$ & $p=0.000$ \\
\hline \multirow[t]{2}{*}{ Trust bank dummy } & $\begin{array}{r}-1.2879 \\
(0.2312)\end{array}$ & $\begin{array}{r}-1.5113 \\
(0.2795)\end{array}$ \\
\hline & $p=0.000$ & $p=0.000$ \\
\hline \multirow[t]{2}{*}{ Regional bank dummy } & $\begin{array}{r}-0.8237 \\
(0.1610)\end{array}$ & $\begin{array}{r}-0.7302 \\
(0.1946)\end{array}$ \\
\hline & $p=0.000$ & $p=0.000$ \\
\hline \multirow[t]{2}{*}{ Employees ${ }^{*}$ trust bank } & $\begin{array}{l}2.95 \mathrm{e}-04 \\
(0.0004)\end{array}$ & $\begin{array}{l}3.41 \mathrm{e}-04 \\
(0.0000)\end{array}$ \\
\hline & $p=0.000$ & $p=0.000$ \\
\hline Employees * regional bank & $\begin{array}{c}2.30 \mathrm{e}-04 \\
(0.0000)\end{array}$ & $\begin{array}{c}2.69 \mathrm{e}-04 \\
(0.0000)\end{array}$ \\
\hline
\end{tabular}

Notes: This Table estimates returns to scale as a function of the number of employees, dummy variables for each type of bank, and interaction terms between employees and bank-type dummy variables (model XV) and estimates returns to density as a function of the same variables (model XVI). Parameter estimates for each coefficient are shown, along with their standard error in parentheses and $p$-value. The regression specification provides an alternative method to using the correlations in Table IX to determine the relationship between scale/density efficiencies and size, within each bank type and across bank types. Model XVII: Estimate of returns to scale $=\alpha+\beta_{1}$ (employees) $+\beta_{2}$ (trust bank) $+\beta_{3}$ (regional bank) $+\beta_{4}$ (employees * trust bank $)+\beta_{5}$ (employees * regional bank). Adj $R$-square: 0.9375. Model XVIII: Estimate of returns to density $=\alpha+\beta_{1}$ (employees) $+\beta_{2}$ (trust bank) $+\beta_{3}$ (regional bank) $+\beta_{4}$ (employees * trust bank) $+\beta_{5}$ (employees* regional bank)/ Adj. $R$-square: 0.9319

\section{Japanese commercial banks}

69
Table XIV. of scale and density on loans, deposits, investments, branches

efficiencies by processing more transactions within their existing branch networks. City banks, on the other hand, had branch networks whose capacity had been exceeded by the number of transactions processed (as seen in their decreasing returns to density estimates) and had high overhead costs for opening up another branch (as seen in their decreasing returns to scale estimates and in the summary statistics on overhead costs). Since further expansion of the saturated, pre-existing city bank network would be costly due to the high overhead costs per branch, city banks could merge with regional banks and enter various prefectures, offering to local companies financial products in which the regional banks traditionally lacked expertise. The resulting greater number of transactions and improved utilization of the branch capacity of regional banks may have yielded cost efficiencies from the merger[15].

Mergers between city banks and trust banks may also have yielded greater efficiencies through greater utilization of the trust banks' branch networks because city banks and trust banks are located in similar geographic areas. Although trust banks could not have exploited cost efficiencies by opening up additional branches (seen in 
$\mathrm{IJMF}$
2,1

70

their constant returns to scale estimates and in their high overhead costs), they did have underutilized branch networks (seen in their increasing returns to density estimates) such that cost efficiencies could be exploited through a merger by using the underutilized trust bank branch network to process more transactions and to offer new products.

In conclusion, mergers can play an important role in stimulating the Japanese economy and in creating stronger, more efficient, and more internationally competitive financial institutions. In the banking industry, an understanding of the steps necessary to achieve economies of scale and density within branch networks is key in creating value-enhancing mergers. This analysis does not refute concerns that issues of market power rather than improvements in efficiency were the motivating factors behind the mega- mergers. Nevertheless, efficient usage of branch networks is not a strategic variable that can be entirely controlled by management, since the volume of transactions undertaken within the network is dependent on demand-side factors, such as the confidence of the public in the banking system. While managers do have the ability to choose types of consolidation which have the potential for improving efficiency, economic and financial reforms enacted by the government to strengthen confidence in the financial system are also key in developing an efficient and internationally competitive banking sector.

\section{Notes}

1. Banks and companies have historically been closely linked together through the main bank system, in which a particular bank and associated banks are the principal lenders to networks of companies (keiretsus) and hold shares in them as a corporate governance mechanism - a topic which is thoroughly dealt with in Hoshi et al. (1990) and Kester (1991).

2. Regional banks, despite their aggregate low value of deposits (and deposits on a per branch basis), have the lowest interest expense per deposit (price of deposits); city banks and trust banks have much higher interest expense per deposit. City banks, whose aggregate value of loans is between that of trust banks and regional banks and whose loans per branch are the highest, have the lowest loan loss provision per loan (the lowest price of loans), closely followed by regional banks. Regional banks have had less exposure to defaulting loans because they have had fewer corporate customers and they have the smallest value of loans per branch, which is why their price of loans is so low. City banks, on the other hand, may have a low price of loans because they may have a learning curve in loan issuance - as the banks issues more loans, their average cost of "producing" loans would fall since they issue loans in sufficient quantities that they become better at identifying good credit risks from bad credit risks. Not adjusting for the number of branches, interest expense was 46 times greater at city banks than at regional banks (eleven times greater at trust banks relative to regional banks) and the loan loss provisions are 14 times greater at city banks relative to regional banks and six-and-a-half times greater at trust banks relative to regional banks.

3. Not surprisingly, due to the high value of loans and investments per branch, city banks and trust banks have interest income per branch which is about seven times greater than at regional banks.

4. Trust banks have the highest non-interest expense per branch, followed by city banks; regional banks' non-interest expense per branch is about one-sixth that of trust banks and about a quarter of that of city banks. Not adjusting for the number of branches, non-interest expenses are 13 times greater for city banks than regional banks and three-and-a-half times greater for trust banks than for regional banks. 
5. A more detailed discussion of the evolution of the use of the translog functional form in scale estimation can be found in Goddard et al. (2001).

6. The "adding-up" condition is that the cost shares of the inputs should sum to one, where the cost share of an input is defined as the costs attributed to that input as a fraction of total cost. The sum of the costs attributed to each input equals total cost. The specification of the cost share equations requires a number of cross-equation coefficient constraints because the coefficients in the cost share equations are the same as the coefficients on some of the terms in the main translog cost function. In addition, some of the coefficients on the cost share equation of one input are constrained to be the same as the coefficients on the cost share equation for another input. This is because the "adding up" restriction that the shares must add to one results in singular residual cross products and disturbance covariance matrices. The singularity of these matrices is rooted in the fact that the disturbances for each observation across equations must add to zero, since the shares must add to one, and M-1 of the $\mathrm{M}$ share equations are linearly independent. Prior to taking natural logarithms, each variable is divided by its mean such that these modified variables are zero when evaluated at their mean (see Caves et al., 1984).

7. The likelihood ratio test between the unrestricted model including investments and the restricted model without investments also confirmed the importance of inclusion of investments - Chi2(9) was 25.23 with a $p$-value of 0.0027 .

8. The dual input and output nature of deposits is discussed in Berger and Humphrey (1997). Furthermore, other studies discussing the advantages of the value-added approach include Berger and Humphrey (1992).

9. The reasons for diminishing returns to density within a given branch network include diminishing returns in the ability to further spread the fixed costs of production over the large volumes of output, as well as diminishing returns in the ability of labor to specialize Scherer and Ross (1990).

10. This is because if the marginal increase in total physical costs across branches from opening a new branch exceeds the marginal increase in transactions undertaken by that branch, then average cost per unit of output rises, although quantity rises-such that the slope of the average cost curve connecting the points is positive and the firm is in the diseconomies region.

11. The concept of underutilization or "under-production" of the smaller, more numerous regional banks relative to the larger, less numerous city and trust banks is consistent with the non-appropriability of social surplus effect, discussed in Dixit and Stiglitz (1977) and Spence (1976), which suggests that monopolistically competitive competition results in "the existing firms producing too little to exhaust returns to scale" (Tirole, 1997).

12. Again, both regressions exhibit statistical significance (evident in the p-values) for all terms, including bank dummies and interaction terms. For example, the specification for model III in Table VII indicates a positive and statistically significant relation between sales and economies of scale for all three types of banks. For trust banks, an increase in sales by 1 unit increases the scale estimates by the sum of the coefficient for sales (4.7e-05) and the coefficient for the interaction term (1.36e-05) between trust banks and sales; for regional banks, its the sum of the coefficient for sales (4.7e-05) and the coefficient of the interaction term between sales and regional banks (5.51e-04); for city banks, its just the coefficient on sales. A similarly positive and statistically significant relationship can be seen between sales and economies of density in model IV.

13. In Table VIII, for model V, the relationship between scale and net income is negative for city banks (coefficient on net income is -1.78e-04), negative for trust banks (sum of -1.78e-04 and -3.43e-05), and negative for regional banks (sum of $-1.78 \mathrm{e}-04$ and $-5.19 \mathrm{e}-05$ ). For model VI, the relationship between density and net income is negative for city banks 


\section{IJMF 2,1}

(coefficient on net income is $-2.42 \mathrm{e}-04$ ), negative for trust banks (sum of $-2.42 \mathrm{e}-04$ and the coefficient on interaction term, which is 5.87e-05), and negative for regional banks (sum of $-2.42 \mathrm{e}-04$ and the coefficient on the interaction term between regional banks and net income, which is $-4.86 \mathrm{e}-04)$.

14. For example, the specification in model VII in Table X indicates a positive relation between loans and scale for all three types of banks - for trust banks, an increase in the value of loans by 1 unit increases the scale estimates by the sum of the coefficient for loans (3.74e-06) and the coefficient for the interaction term (1.96e-05); for regional banks, it's the sum of the coefficient for loans (3.74e-06) and the coefficient of the interaction term between loans and regional banks (2.42e-05); for city banks, its just the coefficient on loans. Model VIII in Table X confirms the positive and statistically significant relation between density and loans for each type of bank: for trust banks, the sum of the coefficient on loans and the coefficient on the interaction term between trust banks and loans is positive; for regional banks, the sum of the coefficient on loans and the coefficient on the interaction term between regional banks and loans is positive; for city banks, the coefficient on loans is positive. All of the coefficients in both Tables are statistically significant.

15. Large Japanese city banks which have limited opportunities to exploit cost efficiencies through further expansion of their branch networks, or through greater utilization of their networks have another alternative - expanding online, which is a lower cost distribution channel. US evidence has suggested that branch banking costs on a per transaction basis are $\$ 1.07$, while internet banking costs on a per transaction basis are $\$ 0.01$ (DeYoung, 2001) During 1999-2000, some of the larger city banks followed this strategy. For example, Bank of Tokyo Mitsubishi, which exhibited the most significant diseconomies of scale and density in the sample expanded online and had 138,000 retail banking customers by mid-2000 (EIU, 2000) Sanwa Bank, second from last in the magnitude of diseconomies of scale and density exhibited, launched e-Wing Securities (EIU, 2000). Sakura Bank, fourth from last in the sample in terms of diseconomies of scale and third from last in diseconomies of density, developed an online bank, Japan Net Bank, along with Fujitsu, Japan's largest computer manufacturer, in addition to developing an ATM network in convenience stores (EIU, 1999, 2000) Fuji Bank launched Fuji Cyberbank, the online unit of the new Mizuho Financial Group (Fuji Bank, Industrial Japan Bank of Japan, Dai-Ichi Kangyo Bank).

\section{References}

Allen, L. and Rai, A. (1996), "Operational efficiency in banking: an international comparison", Journal of Banking and Finance, Vol. 20 No. 3, pp. 655-72.

Altunbas, Y., Liu, H., Molyneux, P. and Seth, R. (2000), "Efficiency and risk in Japanese banking”, Journal of Banking and Finance, Vol. 24 No. 10, pp. 1605-28.

Barrons (2004), Making Sense of a Mega-bank Merger in Japan, July 19, Barrons, Hauppauge, NY.

Batchelor, D., Drake, L. and Simper, R. (2000), "Scale economies and technological change in Japanese banking: an application of an entry/exit model", working paper, Financial Services Authority, London.

Bauer, P.W., Berger, A.N. and Humphrey, D.B. (1993), "Efficiency and productivity growth in US banking", in Fried, H.O., Lovell, C.A.K. and Schmidt, S.S. (Eds), The Measurement of Productive Efficiency: Techniques and Applications, Oxford University Press, Oxford, pp. 386-413.

Benston, G.J., Hanweck, G.A. and Humphrey, D.B. (1982), "Operating costs in commercial banking”, Federal Reserve Bank of Atlanta Economic Review, Vol. 6 No. 1, pp. 6-21. 
Berger, A.N. (1993), "Distribution free estimates of efficiency in the US banking industry and tests of the standard distributional assumptions", Journal of Productivity Analysis, Vol. 4 No. 2, pp. 261-92.

Berger, A.N. and Humphrey, D.B. (1991), "The dominance of inefficiencies over scale and product mix economies in banking", Journal of Monetary Economics, Vol. 28 No. 2, pp. 117-48.

Berger, A.N. and Humphrey, D.B. (1992), "Measurement and efficiency issues in commercial banking", in Griliches, Z. (Ed.), Output Measurement in the Service Sectors, National Bureau of Economic Research Studies in Income and Wealth, University of Chicago Press, Chicago, IL.

Berger, A.N. and Humphrey, D.B. (1997), "Efficiency of financial institutions: international survey and directions for future research", European Journal of Operations Research, Vol. 98 No. 2, pp. 175-212.

Berger, A.N., Leusner, J.H. and Mingo, J.J. (1997), "The efficiency of bank branches", Journal of Monetary Economics, Vol. 40 No. 3, pp. 141-62.

Caves, D.W., Laurits, R.C. and Trethaway, M.W. (1984), "Economies of density versus economies of scale: why trunk and local service airline costs differ", Rand Journal of Economics, Vol. 15 No. 4, pp. 471-89.

DeYoung, R. (2001), The Internet's Place in the Banking Industry, Federal Reserve Bank of Chicago, Chicago, IL.

Dixit, A. and Stiglitz, J. (1977), "Monopolistic competition and optimum product diversity", American Economic Review, Vol. 67 No. 2, pp. 297-308.

Doukas, J. and Switzer, L. (1991), "Economies of scale and scope in Canadian branch banking", Journal of International Financial Markets, Institutions, and Money, Vol. 1 No. 1, pp. 61-84.

(The) Economist (2000), "Finance and economics: merging, Japan-style", The Economist, March 18.

(The) Economist (2002), "Finance and economics: outsmarting their city cousins: regional banks in Japan", The Economist, April 6.

(The) Economist (2004), "Finance and economics: hostile towards whom? Japanese banks", The Economist, August 28.

EIU (1999), Country Finance Report for Japan, Economist Intelligence Unit, New York, NY.

EIU (2000), Country Finance Report for Japan, Economist Intelligence Unit, New York, NY.

European Commission (1997), Impact on Services: Credit Institutions and Banking, European Commission, Geneva.

Fanjul, O. and Maravall, F. (1985), La eficiencia del sistema bancario Español, research paper, Alianza University, Madrid.

Friedman, B. (2000), "Japan now and the United States then: lessons from the parallels", in Mikitani, R. and Posen, A. (Eds), Japan's Financial Crisis and its Parallels to the US Experience, Institute for International Economics, Washington, DC, pp. 37-56.

Fukuyama, H. (1993), "Technical and scale efficiency of Japanese commercial banks: a non-parametric approach", Applied Economics, Vol. 25 No. 8, pp. 1101-12.

Gathon, H. and Grosjean, F. (1991), "Efficacité productive et rendement d'echelle dans les banques belges", Cahiers Economiques de Bruxelles, Vol. 144, pp. 145-60.

Goddard, J., Molyneux, P. and Wilson, J. (2001), European Banking: Efficiency, Technology, and Growth, John Wiley \& Sons, New York, NY.

Hensel, N.D. (2003), "Strategic management of cost efficiencies in networks: cross-country evidence on European branch banking", European Financial Management Journal, Vol. 9 No. 3, pp. 333-60. 
IJMF

2,1
Hoshi, T., Kashyap, A. and Scharfstein, D. (1990), "Bank monitoring and investment: evidence from the changing structure of Japanese corporate banking relationships", in Hubbard, R.G. (Ed.), Asymmetric Information, Corporate Finance, and Investment, University of Chicago Press, Chicago, IL, pp. 105-26.

Jagtiani, J. and Khanthavit, A. (1996), "Scale and scope economies at large banks: including off-balance sheet products and regulatory effects: 1984-1991", Journal of Banking and Finance, Vol. 20 No. 9, pp. 1271-87.

Jagtiani, J., Nathan, A. and Sick, G. (1995), "Scale economies and cost complementarities in commercial banks: on- and off-balance sheet activities", Journal of Banking and Finance, Vol. 19 No. 8, pp. 1175-89.

Keren, M. and Levhari, D. (1983), "The internal organization of the firm and the shape of average costs", Bell Journal of Economics., Vol. 14 No. 3, pp. 474-86.

Kester, W.C. (1991), Japanese Takeovers: The Global Contest for Corporate Control, Harvard Business School Press, Boston, MA.

Kolari, A. and Zardkoohi, J. (1987), Bank Cost, Structure, and Performance, Lexington Books, Lexington, MA.

McAllister, P.H. and McManus, D. (1993), "Resolving the scale efficiency puzzle in banking", Journal of Banking and Finance, Vol. 17 No. 3, pp. 389-405.

McKillop, D.G., Glass, C.J. and Morikawa, Y. (1996), "The composite cost function and efficiency in Japanese banks", Journal of Banking and Finance, Vol. 20 No. 9, pp. 1651-71.

New York Times (2004), "Tentative merger deal in Japan to create largest bank", New York Times, August 13.

Pavlopoulos, P. and Kouzelis, A. (1989), "Cost behavior in the banking industry: evidence from a Greek commercial bank", Applied Economics, Vol. 21 No. 2, pp. 285-93.

Rafferty, K. (2000), "Some signs of an urge to merge", Euromoney, October.

Rodriguez, J.R.O., Alvarez, A.A. and Gomez, P.P. (1993), Scale and Scope Economies in Banking: A Study of Savings Banks in Spain, Universidad de la Laguna, Tenerife.

Saunders, A. and Cornett, M.M. (2002), Financial Institutions Management, 4th ed., McGraw-Hill, New York, NY.

Scherer, F.M. and Ross, D. (1990), Industrial Market Structure and Economic Performance, 3rd ed., Houghton Mifflin, Boston, MA.

Shaffer, S. (1993), “Can megamergers improve bank efficiency?”, Journal of Banking and Finance, Vol. 17 No. 4, pp. 423-36.

Spence, M. (1976), "Product selection, fixed costs, and monopolistic competition", Review of Economic Studies, Vol. 43 No. 2, pp. 217-35.

Tirole, J. (1997), The Theory of Industrial Organization, MIT Press, Cambridge, MA.

Vander Vennet, R. (1996), "The effects of mergers and acquisitions on the efficiency and profitability of EC credit institutions", Journal of Banking and Finance, Vol. 20 No. 9, pp. 1531-58.

Wall Street Journal (1999), "Mergers as medicine", Wall Street Journal, January 27.

Wall Street Journal (2004), "New deal: banks fight to the end, but Japan won't be the same”, Wall Street Journal, August 17.

Williamson, O.E. (1967), "Hierarchical control and optimum firm size", Journal of Political Economy, Vol. 75 No. 2, pp. 123-38.

Williamson, O.E. (1970), Corporate Control and Business Behavior, Prentice-Hall, Englewood Cliffs, NJ. 
Zardkoohi, A. and Kolari, J. (1994), "Branch office economies of scale and scope: evidence from savings banks in Finland", Journal of Banking and Finance, Vol. 18 No. 4, pp. 421-32.

\section{Further reading}

Asia Pulse (2002), "Profile: Japan's banking industry", Asia Pulse, May 16.

Berger, A.N., Hanweck, G. and Humphrey, D. (1986), Competitive Viability in Banking: Scale, Scope, and Product Mix Economies, Research Papers in Banking and Financial Economics, Board of Governors of the Federal Reserve System, Washington, DC.

Berndt, E.R. (1996), The Practice of Econometrics: Classic and Contemporary, Addison-Wesley, Reading, MA.

Caves, D.W., Laurits, W.C., Trethaway, M.W. and Windle, R.J. (1984), "Network effects and the measurement of returns to scale and density for US railroads", Analytical Studies in Transport Economics, Cambridge University Press, Cambridge, pp. 97-120.

Financial Times (2001), “Japan set to duck key banking reform”, Financial Times, March 21.

Gale, D. (1993), Branch Banking, Unitary Banking, and Competition, mimeograph, Department of Economics, Boston University, Boston, MA.

Goldberg, L.G., Hanweck, G.A., Keenan, M. and Young, A. (1991), "Economies of scale and scope in the securities industry", Journal of Banking and Finance, Vol. 15 No. 1, pp. 91-107.

Greene, W.H. (1997), Econometric Analysis, Prentice-Hall, Upper Saddle River, NJ.

Haggard, S. (2000), The Political Economy of the Asian Financial Crisis, Institute for International Economics, Washington, DC.

Hensel, N.D. (2000), "Banking regulation and reform: implications for the new millennium", The New Millennium: Challenges and Strategies for the Globalizing World, Ashgate Press, Aldershot, pp. 197-212.

Hensel, N.D. (2001), "Essays on consolidation and efficiency in network-based industries", PhD dissertation.

Hensel, N.D. (2002), "The implications of strategic network management for firm behavior", Journal of Financial Transformation, Vol. 4 No. 1, pp. 29-35.

Hoshi, T. and Kashyap, A. (1999), "The Japanese banking crisis: where did it come from and how did it end?”, working paper, No. W7259, National Bureau of Economic Research, Cambridge, MA.

Jorgenson, D.W. (1986), "Econometric methods for modeling producer behavior", Handbook of Econometrics, Chapter 31, Vol. 3, North-Holland, Amsterdam, pp. 1841-915.

Kaplan, S.N. and Minton, B.A. (1993), “Outside' intervention in Japanese companies: its determinants and its implications for managers", working paper, No. 4276, National Bureau of Economic Research, Cambridge, MA.

Kester, W.C. (1994), "Banks in the boardroom: the American versus Japanese and German experiences”, Global Finance Journal, Vol. 5 No. 2, pp. 181-204.

Mattione, R.P. (2000), "Japan: the world's slowest crisis", The Asian Financial Crisis, Vol. 185 No. 18 , pp. 181-204.

Mikitani, R. (2000), "The facts of the Japanese financial crisis", in Mikitani, R. and Posen, A.S. (Eds), Japan's Financial Crisis and its Parallels to the US Experience, Institute for International Economics, Washington, DC, pp. 27-36.

Office for Official Publications of the European Communities (1996), Single Market Review, Subseries II, Vol. 4, Office for Official Publications of the European Communities, London. 
IJMF

2,1
Piloff, S.J. (1999), "Does the presence of big banks influence competition in local markets?", Journal of Financial Services Research, Vol. 15 No. 3, pp. 159-77.

Posen, A.S. (2000), "Introduction: financial similarities and monetary differences", in Mikitani, R. and Posen, A.S. (Eds), Japan's Financial Crisis and its Parallels to US Experience, Institute for International Economics, Washington, DC, pp. 1-26.

Prager, R.A. and Hannan, T. (1998), "Do substantial horizontal mergers generate significant price effects? Evidence from the banking industry", Journal of Industrial Economics, Vol. 46 No. 4, pp. 433-51.

Retail Banker International (2002a), "World's biggest bank crashes on takeoff”, Retail Banker International, April 15.

Retail Banker International (2002b), "Japanese regional banks under threat", Retail Banker International, July 31.

Robinson, E.A.G. (1958), The Structure of Competitive Industry, University of Chicago Press, Chicago, IL.

Sachs, J. and Woo, W.T. (2000), "Understanding the Asian crisis", in Sachs, J. and Woo, W.T. (Eds), Asian Crisis: Lessons for a Resilient Asia, MIT Press, Cambridge, MA, pp. 13-43.

Sheard, P. (1992), "The role of the Japanese main bank when borrowing firms are in financial distress”, Discussion Paper, No. 330, Center for Economic Policy Research, Washington, DC, p. 330.

Sheard, P. (1994a), "Bank executives on Japanese corporate boards", Bank of Japan Monetary and Economic Studies, Vol. 12 No. 2, pp. 85-121.

Sheard, P. (1994b), "Reciprocal delegated monitoring in the Japanese main bank system", Journal of the Japanese and International Economies, Vol. 8 No. 1, pp. 1-21.

Shimizu, Y. (2000), "Convoy regulation, bank management, and the financial crisis in Japan", in Mikitani, R. and Posen, A.S. (Eds), Japan's Financial Crisis and its Parallels to the US Experience, Institute for International Economics, Washington, DC, pp. 57-100.

Wall Street Journal (1999), "Sanwa bank is facing a world of giants: Japanese institution finds itself without a partner as rivals plan to merge", Wall Street Journal, October 29.

Woo, W.T., Sachs, J. and Schwab, K. (Eds) (2000), "Lessons for a resilient Asia”, MIT Press, Cambridge, MA, pp. 185-201.

\section{Corresponding author}

Nayantara D. Hensel can be contacted at: ndhensel@nps.edu or nhensel@post.harvard.edu 